\title{
THE EFFECT OF CORE CONFIGURATION ON THE COMPRESSIVE PERFORMANCE OF METALLIC SANDWICH PANELS
}

\author{
VPLIV KONFIGURACIJE JEDRA NA OBNAŠANJE KOVINSKIH \\ SENDVIČ PANELOV POD TLAČNO OBREMENITVIJO
}

\author{
Erman Zurnaci $^{{ }^{*}}$, Hasan Gökkaya ${ }^{2}$ \\ ${ }^{1}$ Department of Electronic and Automation, Dr. Engin Pak Cumayeri Vocational School, Düzce University, 81620 Düzce, Turkey \\ ${ }^{2}$ Department of Mechanical Engineering, Faculty of Engineering, Karabük University, 78050 Karabük, Turkey
}

Prejem rokopisa - received: 2019-01-25; sprejem za objavo - accepted for publication: 2019-07-10

doi: $10.17222 /$ mit.2019.023

\begin{abstract}
The compressive performance of metallic sandwich panels signifies a key mechanical behaviour under compression loading. This paper describes the compressive performance of metallic corrugated core sandwich panels having different core configurations under quasi-static compression loads. Two different sandwich panel core configurations were studied: the corrugated monolithic core and the corrugated sliced core. The corrugated cores were fabricated using a sheet-metal bending technique with trapezoidal geometry and then bonded to surface plates. Aluminium $1050 \mathrm{H} 14$ sheets were used as the core and surface materials. Sandwich panel samples were prepared and tested experimentally under a quasi-static compression load (compression rate of $2 \mathrm{~mm} / \mathrm{min}$ ). The force-displacement curves of the sandwich panels with different core configurations were obtained from the experimental tests. The compressive performance parameters included the maximum compression load, the average compression load, the energy absorption and the specific energy absorption. It was found that the core configuration played a key role in the compressive performance. Finally, when the compressive performance of these two different core configurations was compared, the corrugated sliced-core configurations exhibited better performance.

Keywords: metallic sandwich panel, corrugated core configuration, compressive performance, energy-absorption capacity
\end{abstract}

Poznavanje mehanskega obnašanja kovinskih sendvič panelov pod tlačno obremenitvijo, je ključno za njihovo optimalno uporabo v različnih konstrukcijah. V članku avtorji opisujejo obnašanje sendvič panelov z vgrajenimi nagubanimi kovinskimi jedri (vložki), z različno konfiguracijo (obliko in lego), pod kvazistatično (zelo počasno, na videz statično) tlačno obremenitvijo. Analizirali so dve različni konfiguraciji kovinskih jeder, vgrajenih v sendvič panele; prvo jedro je bilo nagubano monolitno jedro in drugo, sestavljeno iz posameznih nagubanih rezin, zloženih v kompaktno jedro. Nagubano kovinsko jedro je bilo izdelano s pomočjo tehnike trapezoidnega krivljenja kovinske pločevine iz Al $1050 \mathrm{H} 14$, ki je bilo nato pritrjeno na plošče iz istega materiala. Iz tako pripravljenih sendvič panelov, so izrezali preizkušance in jih eksperimentalno kvazistatično tlačno obremenjevali s hitrostjo obremenjevanja $2 \mathrm{~mm} / \mathrm{min}$. Na ta način so eksperimentalno določili krivulje sila-pomik sendvič panelov z različno konfiguracijo jeder. Pri tem so eksperimentalno določili naslednje mehanske parametre obnašanja panelov pod tlačno obremenitvijo: maksimalno tlačno obremenitev, povprečno tlačno obremenitev, energijo absorpcije in specifično energijo absorpcije. Ugotovili so, da ima konfiguracija jedra ključno vlogo pri odpornosti kovinskih sendvič panelov proti tlačnim obremenitvam. V zaključku avtorji tudi ugotavljajo, da imajo sendvič paneli z jedrom iz posameznih nagubanih rezin boljšo odpornost proti tlačnim obremenitvam, v primerjavi s sendvič paneli z monolitnim nagubanim jedrom.

Ključne besede: kovinski sendvič paneli, konfiguracija z nagubanim jedrom, odpornost proti tlačnim obremenitvam, sposobnost za absorpcijo energije

\section{INTRODUCTION}

Metallic sandwich panels are used as the structural components in various industries, including the defence, transportation, space and shipbuilding sectors, due to their light weight and high energy-absorbing capacity. ${ }^{1-3}$ Sandwich panels are comprised of a thick but light core placed between two thin surface plates. ${ }^{4,5}$ The light core structure provides a high energy damping capacity, while the surface plates provide great shear strength and bending resistance. ${ }^{6}$ Sandwich panels with a corrugated core are widely used because of their low cost, ease of production, low density and advanced mechanical properties. ${ }^{7,8}$ Metallic corrugated cores provide effective

*Corresponding author's e-mail:

ermanzurnaci@duzce.edu.tr (Erman Zurnaci) impact resistance and a high energy-absorbing capacity. ${ }^{9}$ The trapezoidal core geometry is often preferred in corrugated core sandwich panel design as it has a positive effect on the mechanical performance of the sandwich panel. ${ }^{10,11}$ The corrugated core form is composed of continuously repeating unit cells and these repetitive unit cells act as a network structure. ${ }^{12}$

During their service life, sandwich panels can be subjected to various impact damages due to bird strikes, hailstones, blasts of water, vehicle crashes and so on. ${ }^{13}$ The impact resistance is directly related to the compressive performance of the sandwich panels. The compressive performance of the panels is largely influenced by the core structure. For this reason, it is important to explore the effect of corrugated core configuration in order to achieve better compressive performance outcomes. 
Numerous experimental and numerical investigations on the impact performance of corrugated core sandwich panels are available in the literature. For example, F. Côté et al. ${ }^{14}$ revealed that when tested in the longitudinal direction, the corrugated core structure provided a significantly greater shear strength compared to square honeycomb and diamond cores. Another study by K. Dharmasena et al. ${ }^{15}$ examined experimentally and numerically the dynamic crushing response of multilayered corrugated sandwich panels under impetuous loads. They found that multilayer sandwich structures significantly reduced the severity of the impetuous loads. D. D. Radford et al. ${ }^{16}$ investigated the responses of triangular corrugated, pyramidal and bulk aluminium foam core sandwich plates subjected to shock loading. They found that the corrugated and metal foam core sandwich panels exhibited the highest shock resistance, while the pyramidal core was the weakest of the sandwich beams. M. T. Tilbrook et al. ${ }^{17}$ studied the dynamic out-of-plane compressive response of stainless steel corrugated and Y-frame sandwich cores for different impact velocities. The results showed that plastic wave effects within the core structures result in the upper face stresses, while the lower face stresses remain approximately constant. S. Hou et al. ${ }^{18}$ investigated the relationship between the structural behaviours and the impact resistance of corrugated core metallic sandwich panels having a different core geometry under low-velocity, local, and in-plane impacts. The results of the analyses revealed that when the thickness of the surface plates, the core height, and the core density were kept constant, the core-cell geometry had a relatively small effect under the low-velocity local impact load. Other researchers also investigated the impact performance of metallic sandwich panels using numerical and experimental test methods. ${ }^{19-23}$ These studies have shown that the design optimisation of sandwich panels is effective in improving their performance. In the present study, the effect of different core configurations on the compressive performance of metallic corrugated core sandwich panels was investigated experimentally under a quasi-static compression load. The compressive performance parameters of sandwich panels having different core configurations were calculated. In addition, the results of the experimental tests for different core configurations were compared.

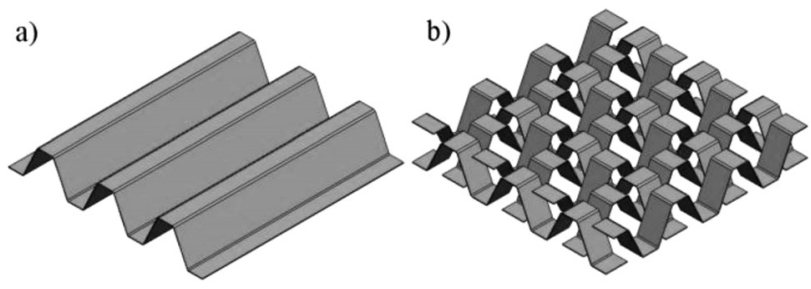

Figure 1: Core configurations: a) corrugated monolithic core and b) corrugated sliced core

\section{EXPERIMENTAL PART}

\subsection{Experimental samples}

In this study, two different core configurations, a corrugated monolithic core and a corrugated sliced core (Figure 1), were studied to reveal the effect of the core configuration on the compression performance of the sandwich panels. A trapezoidal geometry was determined as the core form. The geometrical parameters of a unit cell are given in Figure 2.

Sandwich panel samples consisted of three components: 1) a corrugated core, 2) surface plates and 3) an adhesive layer. Aluminium 1050 H14 sheets were used as the core and surface plate material of the sandwich panel samples. The thickness of the core and surface plates were, respectively, $0.2 \mathrm{~mm}$ and $1 \mathrm{~mm}$. To determine the stress-strain responses of the Al $1050 \mathrm{H} 14$ material, tensile tests were performed at room temperature using a Zwick/Roell Z600 universal testing machine with a $600-\mathrm{kN}$ loading capacity. The test samples were sliced from aluminium sheets using wire electric discharge machining in accordance with the American Society for Testing of Materials standard (ASTM E8M-04). ${ }^{24}$ The gauge length and thickness of the samples were $50 \mathrm{~mm}$ and $1 \mathrm{~mm}$, respectively, as shown in Figure 3a, and three different tensile samples were tested. The tensile-test curve is shown in Figure 3b. The material properties of the Aluminium 1050 H14 were obtained via tests and are listed in Table $\mathbf{1 .}$

Table 1: Material properties of aluminium $1050 \mathrm{H} 14$ sheet

\begin{tabular}{|c|c|c|c|c|}
\hline $\begin{array}{c}\text { Density } \\
\left(\mathrm{kg} / \mathrm{m}^{3}\right)\end{array}$ & $\begin{array}{c}\text { Elastic } \\
\text { modulus } \\
(\mathrm{GPa})\end{array}$ & $\begin{array}{c}\text { Poisson } \\
\text { ratio }\end{array}$ & $\begin{array}{c}\text { Yield stress } \\
(\mathrm{MPa})\end{array}$ & $\begin{array}{c}\text { Ultimate } \\
\text { stress } \\
(\mathrm{MPa})\end{array}$ \\
\hline 2634 & 40 & 0.33 & 100 & 108 \\
\hline
\end{tabular}

The corrugated sliced-core configuration was created by slicing the corrugated monolithic core and placing it on the surface plate of the panel in different directions and angles. The unit-cell widths of the corrugated sliced core and corrugated monolithic core were $6.8 \mathrm{~mm}$ and 64 $\mathrm{mm}$, respectively. The corrugated cores of the sandwich panels were prepared by using a custom-made bending mould (Figure 4a). Each sandwich panel sample was

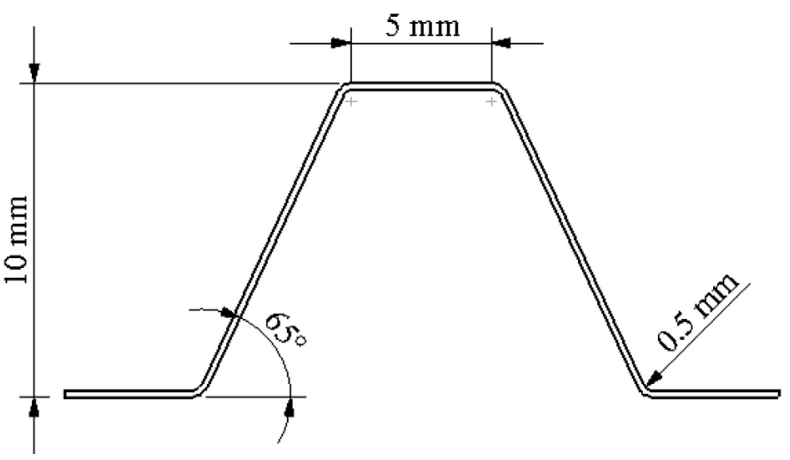

Figure 2: Geometrical parameters of a core unit cell 

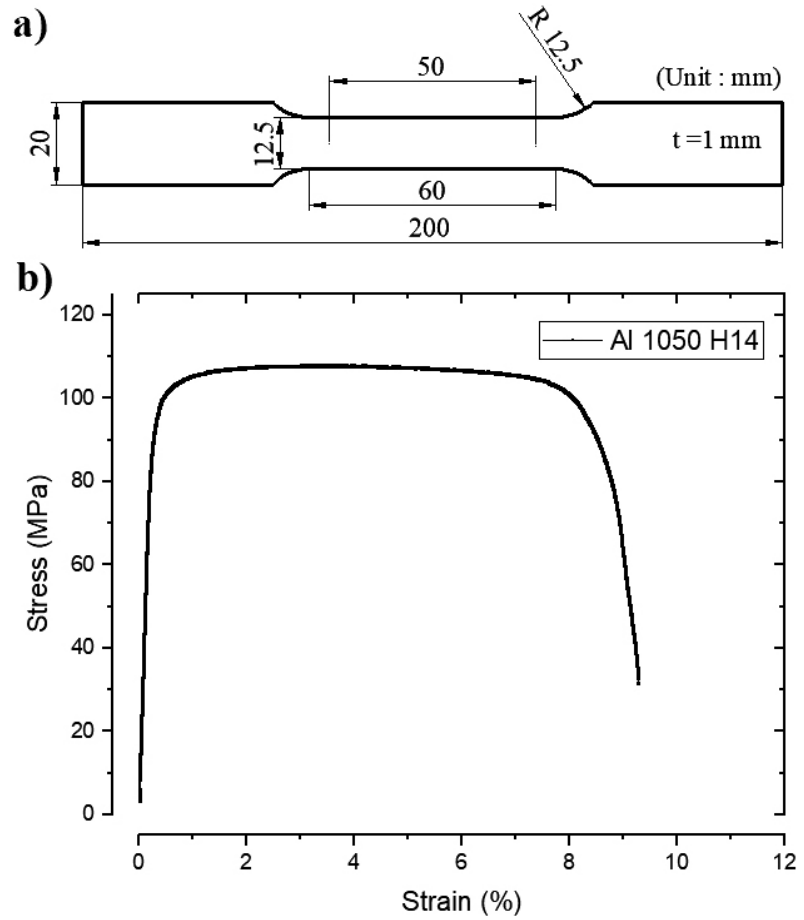

Figure 3: a) Dimensions of tensile samples, b) stress-strain response of Al $1050 \mathrm{H} 14$ material

made of three unit cells. The corrugated core and the surface plates were bonded using a two-component epoxy adhesive layer (Araldite 2015). The prepared samples were held for $24 \mathrm{~h}$ at room temperature in order to cure the adhesive completely. Three samples were prepared for each core configuration. The experimental samples' sizes were $64 \mathrm{~mm}$ in length and width and $12 \mathrm{~mm}$ in height. The average weights $(w)$ for the sequentially corrugated monolithic core and corrugated sliced-core sandwich panel samples were $26.485 \mathrm{~g}$ and $28.544 \mathrm{~g}$, respectively. The prepared samples are shown in Figures $\mathbf{4 b}$ and $\mathbf{4 c .}$

\subsection{Compression tests}

The quasi-static compression tests were conducted at a constant compression rate of $2 \mathrm{~mm} / \mathrm{min}$ in a Zwick/ Roell Z600 testing machine with a capacity of $600 \mathrm{kN}$ in

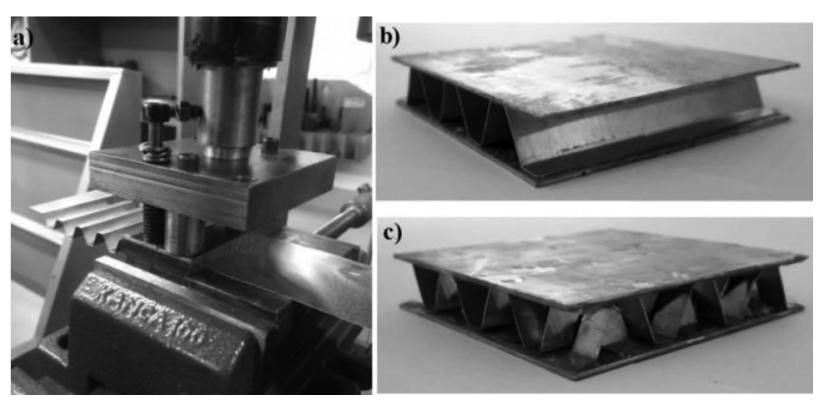

Figure 4: a) Moulding of the cores, sandwich panel samples having different core configurations: b) corrugated monolithic core and c) corrugated sliced core

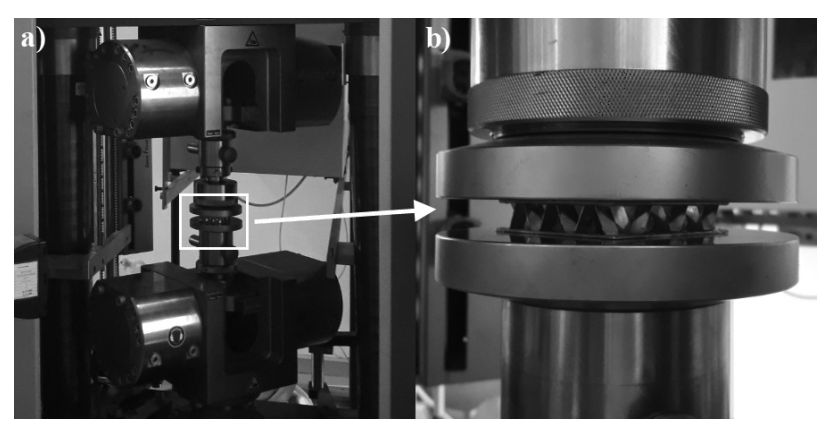

Figure 5: Experimental setup for quasi-static compression loading test

line with the ASTM C365/C365M-11 $\mathrm{a}^{25}$ standards. Figure 5 shows the experimental setup with a sample placed on the clamp of the testing machine. To ensure the accuracy and reproducibility of the test results, at least three tests were conducted for each core configuration, and the average of the measurements was calculated. The load-displacement curves were recorded until the compression reached a value of $8 \mathrm{~mm}$. The samples as they appeared after the compression tests are shown in Figure 6.

\subsection{Compressive performance}

In this study, in order to evaluate and compare the compressive performance of the sandwich panels having different core configurations, the maximum compression load $\left(P_{\max }\right)$, the average compression load $\left(P_{\text {avr }}\right)$, the energy absorption $(E A)$ and the specific energy absorption (SEA) were identified. ${ }^{1}$ The maximum compression load is the initial peak load and occurs in the first stage of the sandwich panel's deformation. The maximum compression load refers to the structural resistance of the sandwich panel under a compression impact load. The energy absorption of the sandwich panel is the integral of the area under the load-displacement curves, as calculated in Equation (1):

$$
E A=\int_{0}^{\delta} P \mathrm{~d} \delta
$$

where $\delta$ is the compression distance, and $P$ is the compression load.

The average compression load represents the mean of the compression load in the deformation process. Specific energy absorption (SEA) is the ratio of the energy

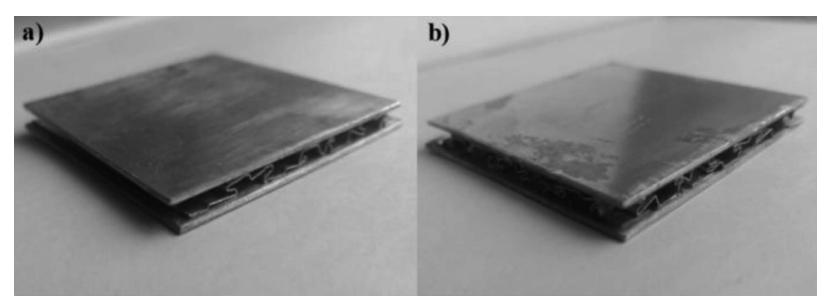

Figure 6: Post-test sandwich panel samples having different core configurations: a) corrugated monolithic core and b) corrugated sliced core 


\section{E. ZURNACI et al.: THE EFFECT OF CORE CONFIGURATION ON THE COMPRESSIVE PERFORMANCE OF METALLIC ...}

absorption to the weight of the sandwich panel samples as in Equation (2):

$$
S E A=\frac{E A}{w}
$$

where $w$ is the average weight of the sandwich panel samples.

The aim was to increase the amount of energy absorption of the sandwich panels to be used as components in engineering applications in order to ensure structural safety. In addition, the specific energy absorption represents the amount of energy absorbed per weight, so this value must be increased in order to reduce the weight of the sandwich panels.

\section{RESULTS}

The load-displacement curves of the sandwich-panel samples having different core configurations are shown in Figure 7. The load-displacement curves represent the behaviour of the sandwich panels under a quasi-static compression load. In order to compare the compressive performances, the load-displacement curves of the
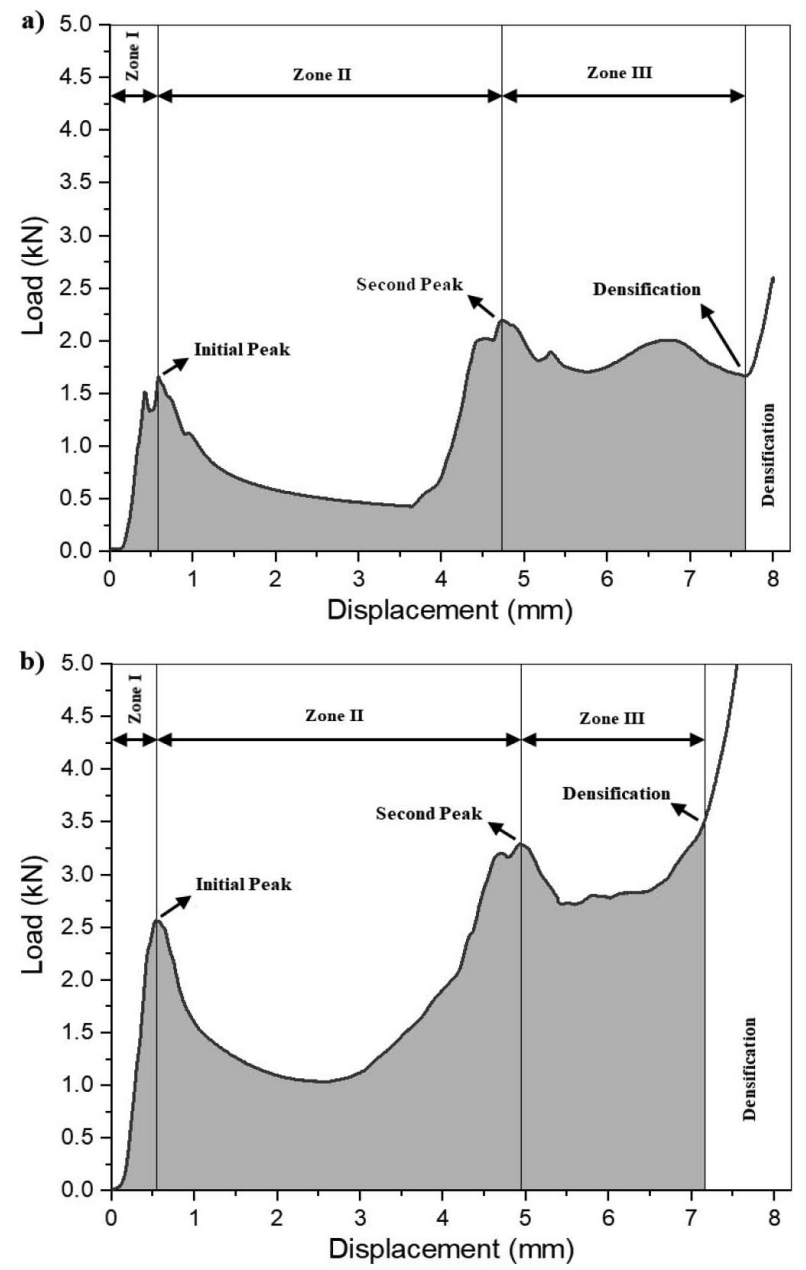

Figure 7: Load-displacement curves and compressive zones: a) corrugated monolithic core and b) corrugated sliced core sandwich-panel samples were examined by dividing into three different compressive Zones (I, II and III).

In the load-displacement curves, the initial peak load shows the first behaviour of the panel against the compressive load. With the start of the compressive loading, all the samples experienced an initial peak load, followed by a sharp drop as the displacement increased. The compressive load increased linearly until the sandwich panel core began to buckle. The initial peak loads were determined as $1.666 \mathrm{kNand} 2.568 \mathrm{kN}$ in the corrugated monolithic core and corrugated sliced-core samples, respectively.

In the load-displacement curves, Zone I was the area from the beginning of the test to the first maximum compression load. This zone shows the first behaviour of the panel against the compression load. Zone II was the area from the first maximum compression load to the second maximum compression load and represents the deformation process in which the panel was subjected to linear compression. Zone III continues until the displacement value of the panel where the impact resistance totally reduced, and the panel was densified. It ends with the end of the deformation of the panel and the completion of the densification. The critical load and displacement values for the two different core configurations are given in Table 2.

Table 2: Critical load and displacement values

\begin{tabular}{|l|c|c|c|c|}
\hline & \multicolumn{2}{|c|}{$\begin{array}{c}\text { Corrugated } \\
\text { monolithic core }\end{array}$} & \multicolumn{2}{c|}{$\begin{array}{c}\text { Corrugated sliced } \\
\text { core }\end{array}$} \\
\hline & $\begin{array}{c}\text { Displacement } \\
(\mathrm{mm})\end{array}$ & $\begin{array}{c}\text { Load } \\
(\mathrm{kN})\end{array}$ & $\begin{array}{c}\text { Displacement } \\
(\mathrm{mm})\end{array}$ & $\begin{array}{c}\text { Load } \\
(\mathrm{kN})\end{array}$ \\
\hline Initial peak & 0.583 & 1.666 & 0.543 & 2.568 \\
\hline Second peak & 4.726 & 2.201 & 4.939 & 3.294 \\
\hline Densification & 7.660 & 1.668 & 7.160 & 3.519 \\
\hline
\end{tabular}

This observation showed that the corrugated slicedcore configuration boosted the initial buckling resistance of the sandwich panel by $54.14 \%$ at the beginning of the deformation. The increase in the compressive strength resulted in a $40 \%$ increase in the amount of energy absorbed. In the curve of the corrugated monolithic core, a sharp decrease was observed after the initial buckling. With the contact of the folded cell walls with the surface plates, a second peak load occurred in the load-displacement curves. The load-displacement curve of the corrugated monolithic core configuration made a smoother transition from the initial peak load to the second peak load. The second peak loads were observed as $2.201 \mathrm{kN}$ and $3.294 \mathrm{kN}$ in the corrugated monolithic core and the corrugated sliced-core samples, respectively. The load-displacement curves increased with the start of the sandwich-panel densification process and ended with its completion. The sandwich panels with the corrugated monolithic core were completely crushed under a compression value of $7.660 \mathrm{~mm}$ and the sandwich panels with the corrugated sliced core were completely crushed as a result of a deformation of $7.160 \mathrm{~mm}$. 
The compressive performance parameters calculated for the two different core configurations are given in Table 3.

Table 3: Compressive performance parameters of different core configurations

\begin{tabular}{|l|c|c|c|c|c|}
\hline & $\begin{array}{c}P_{\max } \\
(\mathrm{kN})\end{array}$ & $\begin{array}{c}P_{\text {avr }} \\
(\mathrm{kN})\end{array}$ & $\begin{array}{c}E A \\
(\mathrm{Joule})\end{array}$ & $\begin{array}{c}S E A \\
(\mathrm{Joule} / \mathrm{g})\end{array}$ & $\begin{array}{c}w \\
(\mathrm{~g})\end{array}$ \\
\hline $\begin{array}{l}\text { Corrugated } \\
\text { monolithic core }\end{array}$ & 1.660 & 1.175 & 9.404 & 0.355 & 26.485 \\
\hline $\begin{array}{l}\text { Corrugated } \\
\text { sliced core }\end{array}$ & 2.568 & 1.806 & 14.448 & 0.506 & 28.544 \\
\hline $\begin{array}{l}\text { Percentage of } \\
\text { change }\end{array}$ & $54.6 \%$ & $53.7 \%$ & $53.6 \%$ & $42.54 \%$ & $7.77 \%$ \\
\hline
\end{tabular}

The compressive performance parameters indicated that the core configuration had an effect on the compressive performance of the sandwich panels. The corrugated sliced-core configuration increased the maximum compression load by $54.6 \%$, while the average crush load was increased by $53.7 \%$. This increase in the maximum compression load of the corrugated slicedcore configuration was achieved by means of slicing the core unit cells and placing them on the surface plate in different directions and angles. Although the corrugated sliced-core configuration increased the weight of the panel by about $7 \%$, it raised the total absorbed energy of the sandwich panel by approximately $53 \%$. The specific energy absorption increased by approximately $42 \%$ due to the increase in the amount of energy damped by the mass.

\section{CONCLUSIONS}

In this study, the corrugated sliced-core configuration was proposed to improve the compressive performance of metallic sandwich panels. Sandwich panels with different core configurations were fabricated and quasi-static compression tests of the sandwich panels were performed. Then the compression behaviours were examined experimentally. Finally, after the experimental investigations, comparisons of their compressive performance configurations were made in detail.

The compressive performance of the sandwich panel having a corrugated sliced-core configuration has substantially improved as compared to the sandwich panel with a corrugated monolithic core configuration with the same size and approximate weight. The rationale is that to the core slices placed on the surface plates in different directions and angles in the corrugated sliced-core configuration. The core slices placed at different directions and angles contributed to the controlled deformation of the core subjected to a quasi-static compression load and distributed the stress caused by the impact force to the entire sandwich panel.

Furthermore, the following conclusions can be drawn based on the experimental observations;
- The results of the experimental tests revealed that the core configuration exerted a significant impact on the compressive performance of the sandwich panels.

- The corrugated sliced-core configuration led to an increase in the initial peak load in the load-displacement curve. This was attributed to the increased compressive strength of the sandwich panel.

- The corrugated sliced-core configuration reduced the compression load oscillation of the panel and increased the compressive strength of the core without an excessive increase in the weight of the sandwich panel.

- Moreover, the corrugated sliced-core configuration increased the energy absorption and average compression load of the sandwich panel.

- Since the sliced-core configuration increased the compression performance without much increase in the panel weight, the specific energy-absorption value also increased.

- It can be concluded that the core configuration had a significant effect on the compressive behaviour of the panel.

The results showed that the compression performance of the sandwich panels can be optimised only by changing the core design. Thus, corrugated sliced-core configuration has a high potential for impact-protection applications where weight and a high energy absorbing capacity are important in metallic sandwich panel constructions. The corrugated sliced-core configuration reduced the compression load oscillation and has, therefore, great potential for the sectors such as transport, defence and space or wherever passenger and structural safety is important.

\section{Acknowledgements}

This work was supported by the Karabük University Coordinatorship of Research Projects, Karabük, Turkey (No. KBÜBAP-17-DR-458).

\section{REFERENCES}

${ }^{1}$ S. Hou, C. Shu, S. Zhao, T. Liu, X. Han, Q. Li, Experimental and numerical studies on multi-layered corrugated sandwich panels under crushing load, Compos. Struct., 126 (2015), 371-385, doi:10.1016/ j.compstruct.2015.02.039

${ }^{2}$ S. Kazemahvazi, D. Zenkert, Corrugated all-composite sandwich structures. Part 1: Modeling, Compos. Sci. Technol., 69 (2009) 7-8, 913-919, doi:10.1016/j.compscitech.2008.11.030

${ }^{3}$ G. Lu, T. X. Yu, Energy absorption of structures and materials, 2nd ed., Cambridge: Woodhead Publishing Ltd., 2003, 424

${ }^{4}$ M. R. M. Rejab, W. J. Cantwell, The mechanical behaviour of corrugated-core sandwich panels, Composites: Part: Engineering, 47 (2013), 267-277, doi:10.1016/j.compositesb.2012.10.031

${ }^{5}$ R. Vescovini, M. D’Ottavio, L. Dozio, O. Polit, Buckling and wrinkling of anisotropic sandwich plates, Int. J. Eng. Sci., 130 (2018), 136-156, doi:10.1016/j.ijengsci.2018.05.010

${ }^{6}$ X. Li, S. Li, Z. Wang, J. Yang, G. Wu, Response of aluminum corrugated sandwich panels under foam projectile impact - Experiment 


\section{E. ZURNACI et al.: THE EFFECT OF CORE CONFIGURATION ON THE COMPRESSIVE PERFORMANCE OF METALLIC ...}

and numerical simulation, Journal of Sandwich Structures \& Materials, 19 (2017) 5, 595-615, doi:10.1177/1099636216630503

${ }^{7}$ C. C. Liang, M. F. Yang, P. W. Wu, Optimum design of metallic corrugated core sandwich panels subjected to blast loads, Ocean Eng., 28 (2001) 7, 825-861, doi:10.1016/S0029-8018(00)00034-2

${ }^{8}$ S. Vaidya, L. Zhang, D. Maddala, R. Hebert, T. W. Jefferson, A Shukla, J. H. Kim, Quasi-static response of sandwich steel beams with corrugated cores, Eng. Struct., 97 (2015), 80-89, doi:10.1016/ j.engstruct.2015.04.009

${ }^{9}$ N. A. Fleck, V. S. Deshpande, The resistance of clamped sandwich beams to shock loading, J. Appl. Mech., 71 (2004) 3, 386-401, doi:10.1115/1.1629109

${ }^{10}$ C. Kılıçaslan, M. Güden, İ. K., A. Taşdemirci, The impact responses and the finite element modeling of layered trapezoidal corrugated aluminum core and aluminum sheet interlayer sandwich structures, Mater. Des., 46 (2013), 121-133, doi:10.1016/j.matdes.2012.09.059

${ }^{11}$ Y. Rong, J. Liu, W. Luo, W. He, Effects of geometric configurations of corrugated cores on the local impact and planar compression of sandwich panels, Composites Part B, 152 (2018), 324-335, doi:10.1016/j.compositesb.2018.08.130

${ }^{12}$ J. Lin, Z. Luo, L. Tong, Design of adaptive cores of sandwich structures using a compliant unit cell approach and topology optimization, Journal of Mechanical Design, 132 (2010) 8, 0810121-0810128, doi:10.1115/1.4002201

${ }^{13}$ M. Meo, R. Vignjevic, G. Marengo, The response of honeycomb sandwich panels under low-velocity impact loading, Int. J. Mech Sci., 47 (2005) 9, 1301-1325, doi:10.1016/j.ijmecsci.2005.05.006

${ }^{14}$ F. Côté, V. S. Deshpande, N. A. Fleck, A. G. Evans, The compressive and shear responses of corrugated and diamond lattice materials, Int J. Solids Struct., 43 (2006) 20, 6220-6242, doi:10.1016/j.ijsolstr. 2005.07.045

${ }^{15}$ K. Dharmasena, D. Queheillalt, H. Chen, P. Dudt, D. Knight, Z. Wei, A. Evans, Dynamic response of a multilayer prismatic structure to impulsive loads incident from water, Int. J. Impact Eng., 36 (2009) 4 632-643, doi:10.1016/j.ijimpeng.2008.06.002
${ }^{16}$ D. D. Radford, N. A. Fleck, V. S. Deshpande, The response of clamped sandwich beams subjected to shock loading, Int. J. Impact Eng., 32 (2006) 6, 968-987, doi:10.1016/j.ijimpeng.2004.08.007

${ }^{17}$ M. T. Tilbrook, D. D. Radford, V. S. Deshpande, N. A. Fleck, Dynamic crushing o sandwich panels with prismatic lattice cores, Int. J. Solids Struct., 44 (2007) 18-19, 6101-6123, doi:10.1016/j.ijsolstr. 2007.02.015.

${ }^{18}$ S. Hou, S. Zhao, L. Ren, X. Han, Q. Li, Crashworthiness optimization of corrugated sandwich panels, Materials and Design Journal, 51 (2013), 1071-1084, doi:10.1016/j.matdes.2013.04.086

${ }^{19}$ J. W. Hutchinson, Z. Xue, Metal sandwich plates optimized for pressure impulses, Int. J. Mech. Sci., 47 (2005), 545-569, doi:10.1016/j.ijmecsci.2004.10.012

${ }^{20}$ V. Rubino, V. S. Deshpande, N. A. Fleck, The dynamic response of Y-frame and corrugated core sandwich beams, Int. J. Solids Struct., 35 (2008) 8, 829-844, doi:10.1016/j.ijimpeng.2007.10.006

${ }^{21}$ Z. Xue, J. W. Hutchinson, A comparative study of blast-resistant metal sandwich plates, Int. J. Impact Eng., 30 (2004) 10, 1283-1305, doi:10.1016/j.ijimpeng.2003.08.007

${ }^{22}$ Y. Liang, A. V. Spuskanyuk, S. E. Flores, D. R. Hayhurst, J. W. Hutchinson, R. M. McMeeking, A. G. Evans, The response of metallic sandwich panels of water blast, J. Appl. Mech., 74 (2007) 1, 81-99, doi:10.1115/1.2178837

${ }^{23}$ Q. H. Qin, J. X. Zhang, T. J. Wang, Low velocity impact response of lightweight metal corrugated sandwich panels with corrugated core, Mater. Res. Innovations, 15 (2011) 1, 198-200, doi:10.1179/ 143307511 X12858956848353

${ }^{24}$ ASTM E8M-04:2004-Standard Specification for Standard Test Methods for Tension Testing of Metallic Materials, ASTM International, West Conshohocken, PA

${ }^{25}$ ASTM C365/C365M-11a:2011-Standard Test Method for Flatwise Compressive Properties of Sandwich Cores, ASTM International, West Conshohocken, PA 